\title{
Transitioning to highly effective therapies for the treatment of chronic hepatitis $C$ virus infection: A policy statement and implementation guideline
}

\author{
Daniel J Smyth MD FRCPC 1,3, Duncan Webster MD FRCPC1,3, Lisa Barrett MD PhD FRCPC ${ }^{2,3}$, \\ Mark MacMillan MD FRCPC ${ }^{1,3}$, Lisa McKnight MD FRCPC ${ }^{1,3}$, Frank Schweiger MD FRCPC ${ }^{1,3}$
}

DJ Smyth, D Webster, L Barrett, M MacMillan, L McKnight, F Schweiger. Transitioning to highly effective therapies for the treatment of chronic hepatitis $\mathrm{C}$ virus infection: $\mathrm{A}$ policy statement and implementation guideline. Can J Gastroenterol Hepatol 2014;28(10):529-534.

Chronic hepatitis $\mathrm{C}$ virus (HCV) infection increases all-cause mortality, rates of cirrhosis, hepatocellular carcinoma, liver transplantation and overall health care utilization. Morbidity and mortality disproportionately affect individuals born between 1945 and 1975. The recent development of well-tolerated and highly effective therapies for chronic HCV infection represents a unique opportunity to dramatically reduce rates of $\mathrm{HCV}$-related complications and their costs. Critical to the introduction of such therapies will be well-designed provincial programming to ensure immediate treatment access to individuals at highest risk for complication, and well-defined strategies to address the global treatment needs of traditionally high-risk and marginalized populations. HCV practitioners in New Brunswick created a provincial strategy that stratifies treatment according to those at highest need, measures clinical impact, and creates evaluation strategies to demonstrate the significant direct and indirect cost savings anticipated with curative treatments.

Key Words: Direct-acting antiviral; Guideline; HCV; Policy; Treatment

\author{
La transition vers des thérapies hautement efficaces \\ pour traiter l'infection par le virus de l'hépatite $\mathrm{C}$ \\ chronique : document de principes et directives de \\ mise en œuvre
}

L'infection par le virus de l'hépatite C (VHC) chronique accroît la mortalité toutes causes confondues, les taux de cirrhose, de carcinome hépatocellulaire et de greffe du foie, ainsi que l'utilisation générale des soins de santé. La morbidité et la mortalité touchent de manière disproportionnée les personnes nées entre 1945 et 1965. La récente mise au point de thérapies bien tolérées et hautement efficaces contre l'infection à $\mathrm{VHC}$ chronique se veut une occasion unique de réduire considérablement le taux de complications et les coûts liés à cette infection. Pour adopter de telles thérapies, il est essentiel de prévoir des programmes provinciaux bien conçus qui assureront un accès immédiat aux personnes les plus vulnérables aux complications, ainsi que des stratégies bien définies pour répondre aux besoins thérapeutiques globaux des populations habituellement à haut risque et marginalisées. Les praticiens du VHC au Nouveau-Brunswick ont créé une stratégie provinciale qui stratifie le traitement en fonction des personnes les plus vulnérables, qui en mesure les répercussions cliniques et qui démontre les économies directes et indirectes importantes anticipées grâce aux traitements curatifs.

reduce rates of chronic liver disease and HCC (9). Incident infections are now primarily concentrated in those engaging in high-risk activities, including intravenous drug use (13), and dedicated programming to minimize high-risk behaviours is essential for a successful comprehensive strategy.

Treatment and subsequent cure of chronic HCV infection reduces the risk of liver failure and HCC, and significantly decreases all-cause mortality (14-16). Treatment of chronic HCV infection currently requires the use of pegylated interferon for up to 48 weeks depending on the viral genotype and response to initial treatment (17). Side effects associated with interferon use are very often debilitating, and include flu-like symptoms, psychiatric complications, endocrinopathies, exacerbation of autoimmune conditions, cytopenias, and severe or life threatening complications (18). The introduction of the novel agents boceprevir and telaprevir allowed the interferon treatment course to be shortened by one-half in certain patient populations, and has increased sustained virological response (SVR) rates to $66 \%$ and $79 \%$ in treatment-naive patients $(19,20)$. Despite these improvements, tolerance of prolonged interferon courses remains challenging and compromises patient adherence to therapy, resulting in significant health care expenditure to manage adverse effects.

We are currently witnessing the introduction of highly effective interferon-free treatment regimens (21). The era of new therapies will create a unique opportunity to offer high clinical cure rates, reduce these patients have been shown to be both cost effective and to

\footnotetext{
${ }^{1}$ Horizon Health Network, New Brunswick; ${ }^{2}$ Capital Health; ${ }^{3}$ Dalhousie University, Halifax, Nova Scotia

Correspondence and reprints: Dr Daniel J Smyth, Department of Medicine, Dalhousie University, 135 MacBeath Avenue, Moncton,

New Brunswick E1C 628. Telephone 506-857-5670, fax 506-857-5671, e-mail dr.daniel.smyth@horizonnb.ca

Received for publication June 4, 2014. Accepted September 8, 2014
} 
hepatic and nonhepatic medical complications, and also increase access to therapy in traditionally marginalized high-risk populations. Patient demand for these highly effective therapies will undoubtedly be intense, and payers - both public and private - will require structured programming to ensure stratified access to appropriate treatment. The current policy addresses the need for appropriate screening strategies, referral and treatment stratification processes, engagement and optimization of marginalized populations and, finally, data collection to evaluate epidemiological, clinical and cost effectiveness.

Understanding the impact of chronic HCV infection will dramatically improve our ability to build and deliver necessary programs for provincial HCV therapy, and target program resources and treatment plans to areas of highest impact. This strategy aims to significantly improve the HCV clinical paradigm in New Brunswick, and the comprehensive prospective approach may act as a benchmark for other provinces to implement similar strategies in their own areas.

\section{METHODS}

All HCV practitioners in New Brunswick were approached for participation in the project. A provincial advisory meeting was held on February 1, 2014 in Rothesay, New Brunswick, with the intention of identifying required resources and creating an optimal care model to facilitate access to and reimbursement of curative HCV treatments in the province.

Breakout sessions focussed discussion on multiple areas including provincial epidemiology, screening, treatment stratification, patient referral and follow-up, and a model of care that recognizes the limited resources currently available. Recommended programming was designed to be implemented in a phased and prioritized fashion, with strategies most likely to be budget neutral and cost effective taking precedence. Implementation tactics were developed for all strategic recommendations.

Following the meeting, subcommittees drafted policy sections related to screening, stratification, treatment, education and prevention, and program evaluation. A consensus document was circulated to all participating members for review before finalization of the following statement.

\section{Implementation proposal}

While there are reasonable data on the number of infected patients and the economic burden of HCV at the national and international level, the same cannot be said of the New Brunswick HCV landscape. $\mathrm{HCV}$ infection is a reportable disease in New Brunswick; however, there is currently no comprehensive provincial strategy for screening or monitoring HCV seroprevalence and new incident cases, especially in high-risk populations.

\section{SCREENING BIRTH COHORT 1945 TO 1975 POPULATION}

$\mathrm{HCV}$ is currently the leading cause of liver cirrhosis, HCC and liver transplantation $(1,2)$. Advanced liver disease caused by HCV is on the rise, particularly in the birth cohort of 1945 to 1975 , who are frequently unaware of their diagnosis $(9,12)$. This results in significant health care expenditure to manage complications. The cost for an individual liver transplant in Organisation for Economic Co-operation and Development countries is approximately $\$ 103,548$. This does not include long-term follow-up and antirejection medication costs (22). Other complications are also costly. The five-year net cost estimates for newly diagnosed HCC patients in Ontario alone are \$106.4 million (23).

To identify these individuals and treat them before complications occur, a screening program for the 1945 to 1975 birth cohort is recommended (24). The Canadian Liver Foundation has issued a position statement advocating for birth-cohort screening in Canada. Screening of the birth cohort born between 1945 and 1975, coupled with a strategy for follow-up treatment and education, is the best method to identify and provide care to affected people in Canada $(24,25)$. New guidelines issued by the Centers for Disease Control and Prevention
(Georgia, USA) suggest that all baby boomers (1945 to 1975) be screened for HCV (26).

\section{Strategic recommendation \\ It is recommended that New Brunswick expand existing HCV screening to include one-time birth cohort screening of individuals born between 1945 and 1975.}

\section{Implementation tactics \\ Tactic 1 A budget impact analysis with incremental cost estimates of birth cohort screening will be provided to the Department of Health and associated laboratories within the Regional Health Authorities. \\ Tactic 2 A primary health education program on birth cohort screening will be developed and implemented, including pathways for subsequent referral. \\ Tactic 3 The screening role of catchment centres such as emergency rooms and addiction services (eg, methadone clinics, correc- tional services) will be evaluated. \\ Tactic 4 Public health education and awareness of the value of HCV screening will be promoted.}

\section{SCREENING: HIGH-RISK POPULATIONS}

Within New Brunswick, cohorts with a high prevalence of HCV infection and at highest risk for new incident HCV infection include users of illicit drugs (IDUs), intravenous drug users (IVDUs), homeless individuals and the incarcerated population. Among IVDU, $50 \%$ to $80 \%$ become infected after one year of intravenous drug use and close to $100 \%$ are infected within eight years. This is due to sharing needles, syringes and other injection equipment, and is associated with at least $70 \%$ to $80 \%$ of newly acquired HCV cases in Canada $(27,28)$. It is estimated that each infected IVDU is likely to infect approximately 20 people, on average, and one-half of these transmissions will take place within two years of the index infection (29). Little is currently known about the prevalence of HCV in New Brunswick IDU and IVDU populations; however, rates are likely very high. In fact, it is known that $42.14 \%$ of 298 opioid-dependent individuals at a New Brunswick methadone maintenance clinic are HCV positive (30).

There are multiple groups at high risk for HCV infection. Homeless individuals have been identified as being at greater risk for infection with blood-borne viruses than the general population (31). Within the correctional system, a projected 30\% of the 14,900 inmates now housed in Canadian federal prisons are infected with HCV (32). It is highly likely that the same issues exist within the provincial corrections system. Certain minority ethnic groups are likely to have acquired HCV infection before immigration to this country. The Public Health Agency of Canada reports that Canadian Aboriginal people are approximately five times more likely than non-Aboriginal people to be infected with viral hepatitis (33). It is also known that in Nova Scotia, there are higher rates of infectious disease among the community members of the largest First Nations community compared with the general population of Cape Breton and Nova Scotia (34). It is unclear whether the First Nations of New Brunswick also have a disproportionate HCV-associated burden of illness.

Targeted screening of these high-risk groups will be essential to identify and treat those at high risk for hepatic adverse events, and to engage persons in critical harm reduction measures necessary to impact incident cases.

\section{Strategic recommendation}

It is recommended that the province of New Brunswick leverage, improve and expand existing provincial screening and related programs among at-risk populations. 


\section{Implementation tactics}

Tactic 1 A coordinated patient intake and referral process will be developed and implemented by existing screening programs, addiction services and methadone clinics.

Tactic 2 Addiction services and methadone clinics will be mandated to screen for $\mathrm{HCV}$.

Tactic $3 \mathrm{HCV}$ at-risk population screening will be promoted to primary health care providers, regional public health offices, correctional services and emergency departments.

Tactic 4 Expansion into under-serviced areas will take place to offer and promote screening for $\mathrm{HCV}$ and other blood-borne diseases to those who attend harm reduction services.

Tactic 5 Public health education on the importance of screening at-risk populations will occur.

Tactic 6 Guidelines will be developed for HCV screening and harm reduction measures in individuals from high-risk endemic countries, First Nations communities and prisons.

\section{TREATMENT STRATIFICATION: RECOMMENDED PATIENT STRATIFICATION BIRTH COHORT}

In light of their excellent tolerance and high cure rates, interferon-free direct-acting antiviral (DAA) treatments will be in high demand by patient groups; however, the up-front direct pharmaceutical cost is significant. It is essential that a utilization management plan is established to ensure prioritization of those most in need and likely to benefit. These criteria, established by provincial HCV experts, will ensure maximal clinical and cost impact. Measureable cost savings in the birth cohort patients provided with curative HCV therapy are anticipated, particularly related to reduced hepatic adverse events. When direct and indirect costs savings are considered, the incremental costs associated with novel HCV therapies are anticipated to be minimal.

\section{Strategic recommendation}

A directed, multiphased treatment and patient stratification strategy is essential to ensure those at highest risk of immediate complication receive prioritized treatment. This approach minimizes up-front expenditure by deferring costs and maximizing potential cost savings.

\begin{tabular}{|c|c|}
\hline Tactic 1 & $\begin{array}{l}\text { Implement patient stratification as a phased multiyear } \\
\text { approach as outlined below. Prioritizing patients based on } \\
\text { their current medical condition and stage of fibrosis. }\end{array}$ \\
\hline \multirow[t]{12}{*}{$\begin{array}{l}\text { Stratification } \\
\text { model }\end{array}$} & $\begin{array}{l}\text { Phase } 1 \text { (short-term, years } 1-2, \text { highest risk of hepatic } \\
\text { adverse event or complication): }\end{array}$ \\
\hline & Fibrosis documented at F3/F4; \\
\hline & Extrahepatic manifestations of chronic HCV infection; \\
\hline & HIV positive; or \\
\hline & At discretion of HCV expert. \\
\hline & $\begin{array}{l}\text { Phase } 2 \text { (years } 3-5 \text {, incorporates lower-risk patients } \\
\text { who are at low risk for reinfection): }\end{array}$ \\
\hline & Fibrosis documented at F2/F3/F4; \\
\hline & Extrahepatic manifestations of chronic HCV infection; \\
\hline & Patient with HCV infection $>10$ years; or \\
\hline & At discretion of HCV expert. \\
\hline & Phase 3 (year $>5$, incorporates most patients): \\
\hline & All remaining patients at discretion of HCV expert. \\
\hline Tactic 2 & $\begin{array}{l}\text { Following identification of chronic HCV infected patients, it } \\
\text { is recommended to adopt and improve the existing referral } \\
\text { plan directed to specialists at the HCV collaborative care } \\
\text { clinics for program enrollment, assessment and treatment. }\end{array}$ \\
\hline Tactic 3 & $\begin{array}{l}\text { Expansion of HCV collaborative care clinics to serve rural } \\
\text { populations. }\end{array}$ \\
\hline
\end{tabular}

\section{STRATIFICATION: HIGH-RISK POPULATIONS}

There are several cohorts at increased risk for HCV infection. These cohorts include the baby boomers, IDU and IVDU populations, homeless persons, incarcerated populations, certain minority ethnic groups and First Nations communities. Recognizing the high risks for reinfection and incident infection in IVU and IVDU populations, this strategy suggests initial treatment in these populations to have maximal impact on individual and public health levels.

Despite international recommendations to treat $\mathrm{HCV}$ in the setting of injection and intravenous drug use, there are significant barriers to treating these cohorts, particularly with traditional interferon-containing regimens (35-37). These include concerns around the chaotic lifestyle of IDUs and IVDUs, lack of fixed address, social isolation, poor adherence to treatment, difficulties in the management of the psychiatric side-effects of treatment and risk of reinfection after HCV eradication.

Treating these cohorts in a strategic fashion will contribute to a significant reduction in the prevalence of HCV infection and new incident cases, thus reducing the associated clinical and social burden of the disease within the province. To address these barriers and to successfully contact, manage and treat these patients, a multidisciplinary approach is mandatory with a highly personalized approach to patient care (38). This is best achieved in a coordinated multidisciplinary clinic environment with interprofessional health care. This model of care is utilized at a pilot clinic in Saint John (New Brunswick), operated by the Centre for Research, Education, and Clinical Care of At-Risk Populations (RECAP), and will be an excellent site to test implementation of the multipronged strategy developed by the working group.

\section{RECAP model of care}

A New Brunswick medical model for managing IDU and IVDU cohorts had been established and evaluated (39). Within this model, which employed an interprofessional approach to care, there has been great success with treating $\mathrm{HCV}$ in this difficult-to-treat population. In accordance with the established $\mathrm{WHO}$ patient treatment pathway (40), this model ensures that each patient within at-risk cohorts is provided with an individualized approach to management based on individual circumstances. Following screening, diagnosis and disease staging, patients may be initiated on HCV treatment depending on defined dynamic and static clinical parameters. Patients who are active users of illicit drugs are stabilized before HCV treatment, and individuals meeting criteria for opioid abuse and/or dependence are actively engaged in methadone maintenance programs before starting HCV treatment. Social factors are addressed that will ensure treatment coverage and the ability for close follow-up and communication throughout the course of therapy. After optimization of clinical, mental and social status, and with consideration to other comorbidities, it is determined whether the patient is a candidate for HCV treatment. With the advent and availability of interferon-free treatment regimens, the safe and successful treatment of HCV within this cohort will be more easily attainable. It is anticipated that this will allow for a significant decrease in new incident cases of $\mathrm{HCV}$ within the province.

\section{Strategic recommendation}

At-risk patients require access to a multidisciplinary care model that addresses medical, psychiatric and addiction comorbidities, allowing patients to move toward HCV therapy. Multidisciplinary and interprofessional clinics for the management of HCV-positive and at-risk IDU and IVDU cohorts should be developed, supported, evaluated and promoted.

\section{RECAP patient stratification model}

Tactic 1 Implement patient stratification as a phased multiyear approach. Prioritize patients based on their medical condition, stage of fibrosis and patient readiness for treatment. 


\begin{tabular}{|c|c|}
\hline \multirow[t]{10}{*}{$\begin{array}{l}\text { Stratification } \\
\text { model }\end{array}$} & $\begin{array}{l}\text { Phase } 1 \text { (short-term, year 1-5), highest risk of adverse } \\
\text { event or complication: }\end{array}$ \\
\hline & Fibrosis documented at F3/F4; \\
\hline & Stable on methadone maintenance therapy if indicated; \\
\hline & $\begin{array}{l}\text { Fixed address and adherence to clinic follow-up for } \\
\text { three months; }\end{array}$ \\
\hline & Extrahepatic manifestation of $\mathrm{HCV}$ infection; \\
\hline & HIV positive; or \\
\hline & At the discretion of provincial HCV specialist. \\
\hline & $\begin{array}{l}\text { Phase } 2 \text { (year }>5 \text { ): All patients eligible at discretion of } \\
\text { HCV specialist, providing: }\end{array}$ \\
\hline & $\begin{array}{l}\text { Stable on methadone maintenance therapy if indicated; } \\
\text { and/or }\end{array}$ \\
\hline & $\begin{array}{l}\text { Fixed address and adherence to clinic follow up for three } \\
\text { months or more. }\end{array}$ \\
\hline Tactic 2 & $\begin{array}{l}\text { Expand the RECAP program and model of care in needed } \\
\text { locations across New Brunswick. }\end{array}$ \\
\hline Tactic 3 & $\begin{array}{l}\text { Following successful HCV treatment, patients must be } \\
\text { retained in substance abuse treatment programs with a } \\
\text { focus on harm-reduction to avoid reinfection. }\end{array}$ \\
\hline Tactic 4 & $\begin{array}{l}\text { Ongoing long-term management must also be provided to } \\
\text { those patients not currently suitable for treatment, and } \\
\text { clinical pathways must be developed to assist them in } \\
\text { working toward treatment suitability. }\end{array}$ \\
\hline Tactic 5 & $\begin{array}{l}\text { Aligned collaboration of addiction and mental health services } \\
\text { with the medical model of care in the RECAP program. }\end{array}$ \\
\hline Tactic 6 & $\begin{array}{l}\text { Improved access to methadone maintenance therapy } \\
\text { within the provincial corrections system, and improve } \\
\text { access to methadone prescribers following release. }\end{array}$ \\
\hline Tactic 7 & $\begin{array}{l}\text { Close analysis of HCV treatment outcomes and follow-up } \\
\text { is critical in this difficult-to-treat population. To decrease } \\
\text { new incident cases, the role of treating even the unstable } \\
\text { active addict may be considered in light of program evalu- } \\
\text { ation and trends in HCV prevalence and incidence within } \\
\text { specific communities. }\end{array}$ \\
\hline
\end{tabular}

\section{TREATMENT}

Adherence to traditional interferon-based treatment regimens is often poor, and high indirect costs include employee absence and disability leave to complete therapy. Cost estimates of the current treatment often fail to take into account the significant economic losses resulting from work cessation, disability claims, physician visits, laboratory testing and emergency room visits, among other indirect costs. This does not begin to account for the significant impact these therapies have on quality of life measures. Clearly, the direct drug costs of interferon are small compared with the actual, real-life cost of completing complex and onerous interferon-based therapy.

In clinical trials, interferon-free DAA therapies demonstrate SVR rates ranging from $96 \%$ to $100 \%$ (where SVR is equivalent to viral eradication and cure) $(41,42)$. Treatment-naive patients, patients who have previously failed treatment, and those traditionally difficult to treat including patients with cirrhosis and HIV are almost universally cured with these therapies $(43,44)$. Concomitant use of these treatments in opiate-dependent patients with concomitant methadone use has been studied within the clinical trials, all with high SVR rates.

With the new regimens, treatment will be easier and adherence will be greatly improved. These new therapies represent a significant upgrade from existing therapies currently already covered by the New Brunswick Provincial Drug Plan. Current therapies will quickly become obsolete due to lower SVR rates and diminished cost effectiveness. The combined screening program and high SVR rates of new therapies will likely lead to reduced HCV incidence and provide significant health economic impact for the treating provinces. It is suggested that incremental direct costs related to new treatments in this context will not be significant when compared with traditional interferon-based therapies when direct and indirect cost savings are comprehensively measured. Antiviral treatment will represent just one component of a global and personalized treatment strategy designed to optimize risk factors and medical comorbidities and also to reduce the likelihood of reinfection.

\section{Strategic recommendation}

Expedited access to interferon-free DAA therapies as part of the New Brunswick HCV Strategy for both public and private payers in the context of a comprehensive provincial strategy.

\begin{tabular}{ll} 
Implementation tactics \\
\hline Tactic 1 & $\begin{array}{l}\text { Expedited approval of treatments in the Common Drug } \\
\text { Review and subsequent Pan-Canadian Purchasing Alliance. }\end{array}$ \\
Tactic 2 & $\begin{array}{l}\text { Immediate approval and access to treatment reimburse- } \\
\text { ment on the New Brunswick Provincial Drug Plan for DAA } \\
\text { treatments (as made available to market). }\end{array}$ \\
Tactic 3 & $\begin{array}{l}\text { Immediate approval and access to treatment and reim- } \\
\text { bursement on private insurance plans offered in New }\end{array}$ \\
& $\begin{array}{l}\text { Brunswick (payers). } \\
\text { Tactic } 4\end{array}$ \\
& $\begin{array}{l}\text { Evaluate economic and health outcomes of the New } \\
\text { Brunswick HCV Strategy. Measure and evaluate treatment } \\
\text { adherence, quality of life, patient success, direct medical } \\
\text { savings and indirect cost savings. } \\
\text { Tactic 5 } \\
\text { The use of Fibroscan (Echosens, France) or FibroTest } \\
\text { (LabCorp, USA) technology and other clinical parameters } \\
\text { will assist treating physicians in the allocation of limited } \\
\text { resources to those who will benefit the most early in the } \\
\text { treatment strategy, recognizing that others will need to be } \\
\text { treated in the future. }\end{array}$
\end{tabular}

\section{EDUCATION AND PREVENTION}

Public education is essential in identifying undiagnosed cases of HCV infection in New Brunswick and reducing new cases of HCV infection. Health care practitioners include physicians, nurse practitioners, registered nurses, emergency room staff, pharmacists, support staff and health care trainees. Target patient cohorts for educational initiatives include known HCV-positive individuals, those born from 1945 to 1975, IDU, incarcerated individuals, immigrants from countries of high HCV endemnicity, First Nations communities, and those who received blood products in Canada before 1990. To ensure effectiveness of this screening strategy, all stakeholders in the province, including the Department of Health and Public Health, must collaborate with regard to an educational initiative for these target populations. Key agencies that should participate in this strategy include specialist treatment services, public health, general practitioners, associated community agencies and correctional services. Provision of information will increase awareness of $\mathrm{HCV}$ and will have a subsequent impact on service demand. This must be anticipated and capacity issues addressed through a patient stratification strategy.

The Public Health Agency of Canada is expected to release its review of the Canadian Liver Foundation recommendations in the near future. Currently, it advocates for screening based on risk factors (45). Risk factors include engaging in high-risk behaviours, history of potential exposures to $\mathrm{HCV}$, and clinical signs or symptoms of active disease. For this 'at-risk' group, education is incredibly important to diagnose cases and to prevent new infections. The prevention of new cases is largely through the reduction of transmission of infection from those who are already infected.

The education, prevention and communication approaches completed to date are of value. However, the levels of provision can be described as reactive and patchy rather than strategic and comprehensive. This approach to education and prevention services can 
lead to a situation where the information provided to those at risk is inconsistent and not necessarily based on the latest available evidence. Competency-based standards for training in health promotion do not currently exist in each province for general health promotion or for training in issues relevant to IDU. In addition, there is little to no awareness among health care workers and the general population of the recent Canadian Liver Foundation recommendation for HCV screening among all individuals born between 1945 and 1975.

With regard to IDU and IVDU at-risk populations, a number of agencies within each province are involved in current education, prevention and communication initiatives. Agencies in New Brunswick include, but are not limited to, AIDS Saint John, AIDS New Brunswick, the Atlantic Interdisciplinary Research Network and the Canadian Liver Foundation. Individuals may also receive education around prevention through health care providers at infectious diseases clinics and gastroenterology clinics as well as through public health and addiction services. Education services provided through community advocacy groups are underfunded and there is currently only a modest focus on HCV education through local voluntary providers. Services are targeted at IVDUs and are generally provided on an ad hoc basis. Brief educational interventions are provided to those at risk of $\mathrm{HCV}$ within the formal health care setting.

\section{Strategic recommendation}

A broad public education campaign is required to inform the target populations and, importantly, the 1945 to 1975 birth cohort that HCV screening is recommended regardless of other risk factors. The health care community must also be informed of this recommendation.

\section{Implementation tactics}

Tactic 1 Review existing materials and provide up-to-date accurate and consistent information to all affected by HCV. Specific information will be required by different groups.

The HCV information needs of service providers include: Information pertaining to disease prevalence and incidence, transmission risks, screening \& diagnostic tests, treatment options, treatment benefits and risks

The communication materials and channels include: CMEs and information packages

The information needs of patients diagnosed with HCV include:

Disease characteristics, prognosis, treatment options, treatment benefits and risks, complementary therapies and the means to accessing services

The communication materials and channels include: brochures, posters in all public health access points including pharmacies.

The information needs of high-risk populations such as IVDUs include:

Risk factors, eliminating/minimizing risk, accessing preventative services, disease characteristics, testing for $\mathrm{HCV}$, treatment benefits and risks. French and English material should be used. The communication materials and channels include: Brochures, posters in all public health access points including pharmacies and community based programs.

Tactic 2 Methods of disseminating and providing information and education to different target groups should be evaluated and the most effective approach used. The accuracy of scientific information should be agreed upon and presented in an appropriate format.

Tactic 3 Adopt prevention and education initiatives targeting IVDUs.

Tactic 4 Include competency based training modules on harm reduction for all those working with IDUs in a community setting. Modules should be guided by national standards in health promotion.

\section{PROGRAM EVALUATION}

Measuring therapeutic efficacy and associated health care and societal cost savings are essential to the introduction of novel hepatitis $\mathrm{C}$ treatments. Following informed consent, referred patients will be registered in a provincial database that will collect comprehensive baseline demographic and epidemiological information. Detailed evaluation of comorbidities (medical history, substance abuse history and high-risk behaviours) will be completed and analysis used to guide risk-reduction strategies. The program will establish the efficacy of the implemented risk reduction measures, beginning with the Saint John RECAP clinic.

Data will be gathered and maintained through an integrated patient-centred health information system with an embedded program management platform. Data collected in provincial HCV clinics will be linked to Medicare billing records, and established provincial databases containing valuable indicators including laboratory testing and diagnostic imaging. Longitudinal outcome measures, including emergency room visits, hospitalizations and deaths, will be assessed. The database will establish the safety and efficacy of new therapies in New Brunswick patients, and also evaluate cost savings associated with their use, particularly savings related to a reduction of hepatic adverse events (liver decompensation, HCC and transplantation) and also savings related to reduced usage of health care resources when compared with traditional treatment. Reduced costs related to adverse event management are anticipated, which will offset costs related to the introduction of newer treatment modalities. Side effects from interferon-based therapies also have significant impacts on a patient's ability to work and quality of life, and measureable cost savings related to the improved tolerability of novel agents are anticipated.

The development of the provincial HCV database and proposed evaluation metrics will generate needed clinical outcomes data and health service utilization data. The inclusive patient capture, knowledge generation and translational medicine aspect of this program make it distinctly different from several other nascent programs around the country: potentially all DAA-treated patient data for the province are captured. Understanding the impact of chronic HCV infection will dramatically improve the ability to build and deliver necessary programs for HCV therapy in New Brunswick, and target program resources and treatment plans to areas of highest impact. This proposal will greatly improve the New Brunswick HCV clinical situation; however, the comprehensive approach may also act as a benchmark for other provinces that will need to implement similar strategies in their own regions.

\section{Strategic recommendation}

Measuring therapeutic efficacy and associated health care and societal cost savings are essential to the introduction of novel hepatitis $C$ treatments.

\section{Implementation tactics}

Tactic 1 A prospective provincial database will establish the safety and efficacy of new therapies in New Brunswick, and also evaluate cost savings associated with their use, particularly savings related to a reduction of hepatic adverse events (including liver decompensation, HCC and transplantation) and also savings related to reduced usage of health care resources when compared to treatment with traditional interferon-based regimens.

Tactic 2 The database will establish the efficacy of the implemented risk reduction measures, beginning with the Saint John RECAP pilot clinic. Detailed evaluation of comorbidities will be completed and used to guide future risk reduction strategies.

Tactic 3 Indirect cost savings including those related to employee absence and quality of life will be measured.

\section{CONCLUSION}

The introduction of curative therapies for HCV represents a unique opportunity to significantly improve HCV-related morbidity and mortality in those who are traditionally marginalized and at high risk. 
Utilization management is essential in this context to ensure treatment prioritization to highest-risk patients and to ensure clinical and cost effectiveness. New Brunswick practitioners recognized our unique ability to engage all treating HCV practitioners in the province in the formulation of a comprehensive provincial strategy. Many of the most affected populations in the province are directly applicable to those in other cities and towns across Canada and the United States. We believe the comprehensive program approach developed for New Brunswick patients can act as a benchmark for other provinces to implement similar strategies in a rational, timely manner that can improve HCV care across Canada.

DISCLOSURES: Support for the provincial advisory meeting was provided by Abbvie. The above manuscript was prepared independently by participants following the meeting.

\section{REFERENCES}

1. Lee MH, Yang HI, Lu SN, et al. Chronic hepatitis C virus infection increases mortality from hepatic and extrahepatic diseases: A communitybased long-term prospective study. J Infect Dis 2012;206:469-77.

2. O'Leary JG, Lepe R, Davis GL. Indications for liver transplantation. Gastroenterology 2008;134:1764-76.

3. Moorman AC, Gordon SC, Rupp LB, et al. Baseline characteristics and mortality among people in care for chronic viral hepatitis: The chronic hepatitis cohort study. Clin Infect Dis 2013;56:40-50.

4. Armstrong GL, Wasley A, Simard EP, et al. The prevalence of hepatitis C virus infection in the United States, 1999 through 2002. Ann Intern Med 2006;144:705-14.

5. Canada, Public Health Agency. Canadian Cancer Statistics, 2013. <www.phac-aspc.gc.ca/publicat/cdic-mcbc/33-3/ar-11-eng.php> (Accessed May 1, 2014)

6. El-Serag HB. Epidemiology of hepatocellular carcinoma in USA. Hepatol Res 2007;7(Suppl 2):S88-94.

7. Ly KN, Xing J, Klevens RM, et al. The increasing burden of mortality from viral hepatitis in the United States between 1999 and 2007. Ann Intern Med 2012;156:271-8.

8. Rein DB, Wittenborn JS, Weinbaum CM, et al. Forecasting the morbidity and mortality associated with prevalent cases of pre-cirrhotic chronic hepatitis C in the United States. Dig Liver Dis 2011;43:66-72.

9. Rein DB, Smith BD, Wittenborn JS, et al. The cost-effectiveness of birth-cohort screening for hepatitis $\mathrm{C}$ antibody in U.S. primary care settings. Ann Intern Med 2012;156:263-70.

10. Jacobson IM, Cacoub P, Dal Maso L, et al. Manifestations of chronic hepatitis $\mathrm{C}$ virus infection beyond the liver. Clin Gastroenterol Hepatol 2010;8:1017-29.

11. Arrese M, Riquelme A, Soza A. Insulin resistance, hepatic steatosis and hepatitis C: A complex relationship with relevant clinical implications. Ann Hepatol 2010;9(Suppl):112-8.

12. Brady KA, Weiner M, Turner BJ. Undiagnosed hepatitis $C$ on the general medicine and trauma services of two urban hospitals. J Infect 2009;59:62-9.

13. Centers for Disease Control and Prevention. Hepatitis $C$ virus infection among adolescents and young adults: Massachusetts, 2002-2009. MMWR Morb Mortal Wkly Rep 2011;60:537-41.

14. Morgan TR, Ghany MG, Kim HY, et al. Outcome of sustained virological responders with histologically advanced chronic hepatitis C. Hepatology 2010;52:833-44.

15. Singal AG, Volk ML, Jensen D, et al. A sustained viral response is associated with reduced liver-related morbidity and mortality in patients with hepatitis C virus. Clin Gastroenterol Hepatol 2010;8:280-8, 288 e1.

16. Backus LI, Boothroyd DB, Phillips,BR, et al. A sustained virologic response reduces risk of all-cause mortality in patients with hepatitis $\mathrm{C}$. Clin Gastroenterol Hepatol 2011;9:509-516 e1.

17. Myers RP, Ramji A, Bilodeau M, et al. An update on the management of hepatitis C: Consensus guidelines from the Canadian Association for the Study of the Liver. Can J Gastroenterol 2012;26:359-75.

18. Dusheiko G. Side effects of alpha interferon in chronic hepatitis C. Hepatology 1997;26(3 Suppl 1):112S-121S.

19. Poordad F, McCone J, Bacon BR, et al. Boceprevir for untreated chronic HCV genotype 1 infection. N Engl J Med 2011;364:1195-206.

20. Jacobson IM, McHutchison JG, Dusheiko G, et al. Telaprevir for previously untreated chronic hepatitis $\mathrm{C}$ virus infection. N Engl J Med 2011;364:2405-16.
21. Liang TJ, Ghany MG. Current and future therapies for hepatitis C virus infection. N Engl J Med 2013;368:1907-17.

22. Neff GW, Duncan CW, Schiff ER. The current economic burden of cirrhosis. Gastroenterol Hepatol (N Y) 2011;7:661-71.

23. Thein HH, Isaranuwatchai W, Campetelli,MA, et al. Health care costs associated with hepatocellular carcinoma: A population-based study. Hepatology 2013;58:1375-84.

24. Shah HA, Heathcote J, Feld JJ. A Canadian screening program for hepatitis C: Is now the time? CMAJ 2013;185:1325-8.

25. Canadian Liver Foundation, 2013. Hepatitis C testing. <www.liver.ca/ support-liver-foundation/advocate/clf-position-statements/ hepatitis_C_testing.aspx $>$ (Accessed May 1, 2014).

26. Smith BD, Morgan RL, Beckett GA, et al. Recommendations for the identification of chronic hepatitis $\mathrm{C}$ virus infection among persons born during 1945-1965. MMWR Recomm Rep 2012;61:1-32.

27. Canadian Liver Foundation. Hepatitis C: Medical information update. Can J Public Health 2000;91:S4-S9.

28. Davis GL, Rodrigue JR. Treatment of chronic hepatitis $\mathrm{C}$ in active drug users. N Engl J Med 2001;345:215-7.

29. Magiorkinis G, Sypsa V, Magiorkinis E, et al. Integrating phylodynamics and epidemiology to estimate transmission diversity in viral epidemics. PLoS Comput Biol 2013;9:e1002876.

30. Manzer D, Materniak S, Murugesan A, Webster D. Infectious Diseases Diagnosis, Treatment and Prevention in the Setting of a Medical Model for Methadone Maintenance Therapy. Interprofessional Health Research Day. Saint John, New Brunswick, March 23, 2012.

31. Tompkins CN, Wright NM, Jones L. Impact of a positive hepatitis C diagnosis on homeless injecting drug users: A qualitative study. Br J Gen Pract 2005;55:263-8.

32. Webster PC. Prison puzzle: Treating hepatitis C. CMAJ 2012;184:1017-8.

33. Adelson N. The embodiment of inequity: Health disparities in aboriginal Canada. Can J Public Health 2005;96(Suppl 2):S45-61.

34. Webster D, Weerasinghe S, Stevens P. Morbidity and mortality rates in a Nova Scotia First Nations Community, 1996-1999. Can J Public Health 2004;95:369-74.

35. Edlin BR, Kresina TF, Raymond DB, et al. Overcoming barriers to prevention, care, and treatment of hepatitis $\mathrm{C}$ in illicit drug users. Clin Infect Dis 2005;40(Suppl 5):S276-85.

36. Zanini B, Lanzini A. Antiviral treatment for chronic hepatitis $C$ in illicit drug users: A systematic review. Antivir Ther 2009;14:467-79.

37. Almasio PL, Babudieri S, Barbarini G, et al. Recommendations for the prevention, diagnosis, and treatment of chronic hepatitis B and C in special population groups (migrants, intravenous drug users and prison inmates). Dig Liver Dis 2011;43:589-95.

38. Zanini B, Benini F, Pigozzi MG, et al. Addicts with chronic hepatitis C: Difficult to reach, manage or treat? World J Gastroenterol 2013;19:8011-9.

39. Christie TK, Murugesan A, Manzer D, O'Shaughnessey MV, Webster D. Evaluation of a low threshold/high tolerance methadone maintenance treatment clinic in Saint John, New Brunswick, Canada: One year retention rate and illicit drug use. J Addict 2013:753409.

40. World Health Organization. Guidelines for the screening, care and treatment of persons with hepatitis C infection. April 2014. <www.who.int/hiv/pub/hepatitis/hepatitis-c-guidelines/en/> (Accessed May 1, 2014).

41. Kowdley KV, Gordon SC, Reddy KR, et al. Ledipasvir and sofosbuvir for 8 or 12 weeks for chronic HCV without cirrhosis. N Engl J Med 2014;370:1879-88.

42. Jordan JF, Kowdley, KV, Coakley E, et al, Phase 3 placebo-controlled study of interferon-free, 12-wwek regimen of ABT-450/r/ABT-267, ABT-333 and ribavirin in 631 treatment-naive patients with Hepatitis C virus genotype 1. 49th Annual Meeting of the European Association for the Study of the Liver. London, United Kingdon, April 11, 2014.

43. Afdhal N, Reddy KR, Nelson DR, et al. Ledipasvir and sofosbuvir for previously treated HCV genotype 1 infection. N Engl J Med 2014;370:1483-93.

44. Zeuzam S, Jacobson IM, Baykal T, et al. SAPPHIRE_II: Phase 3 placebo-controlled study of interferon-free, 12-week regimen of ABT450/r/ABT-267, ABT-333, and ribavirin in 394 treatmentexperienced adults with hepatitis $\mathrm{C}$ genotype 1. 49th Annual Meeting of the European Association for the Study of the Liver. London, United Kingdon, April 11, 2014.

45. Pinette G, Coc JJ, Heathcote J, et al. Public Health Agency of Canada, 2009. Primary care management of chronic hepatitis C: Professional desk reference. Ottawa, Ontario. <www.phac-aspc.gc.ca/ hepc/archive-eng.php\#a2009> (Accessed May 1, 2014). 


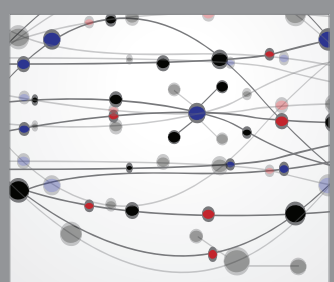

The Scientific World Journal
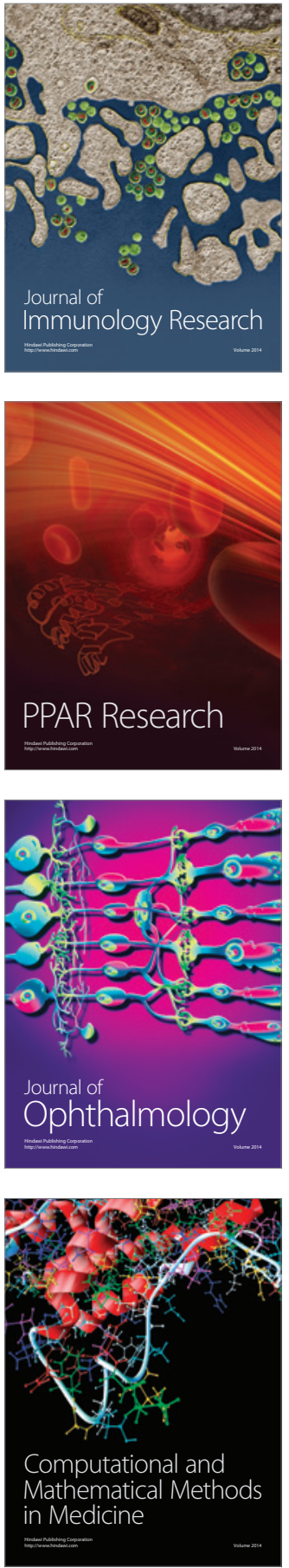

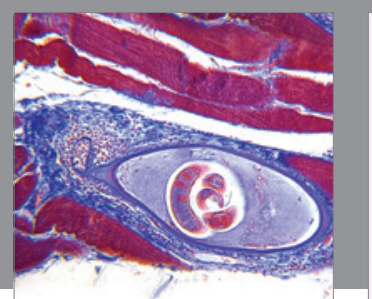

Gastroenterology Research and Practice

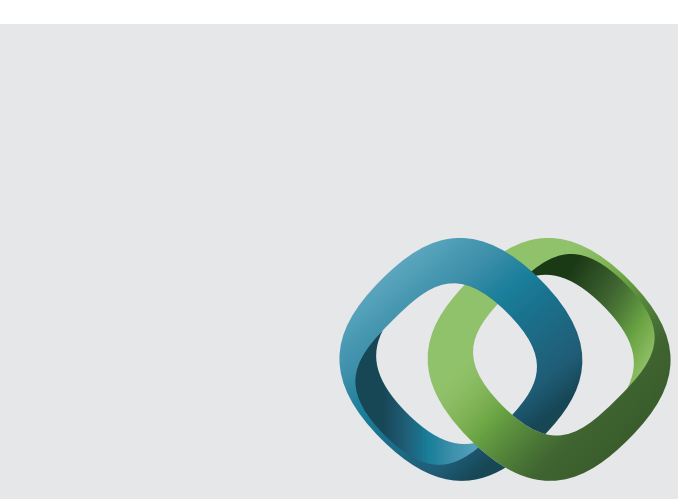

\section{Hindawi}

Submit your manuscripts at

http://www.hindawi.com
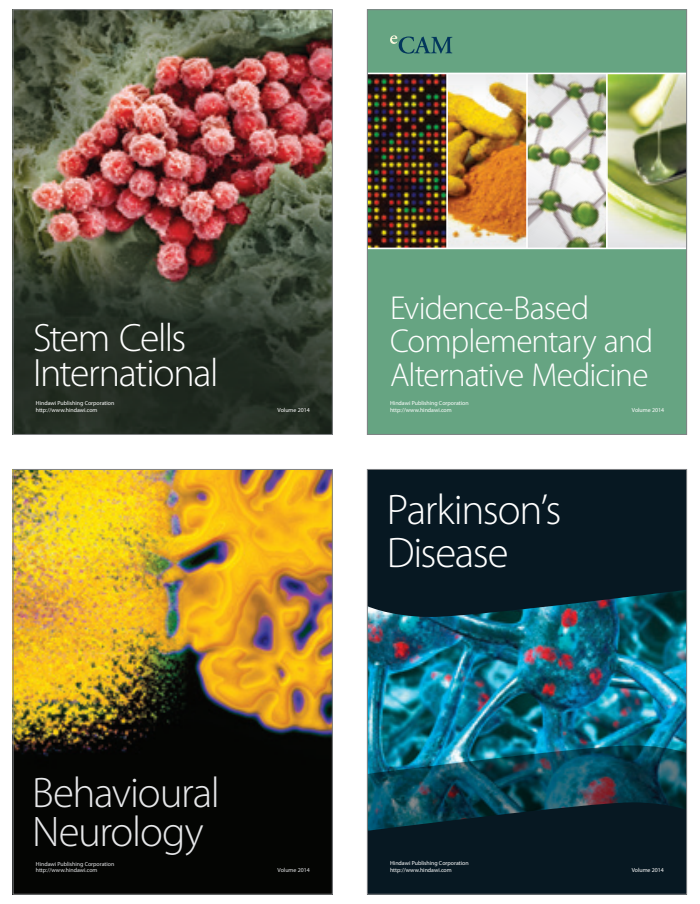
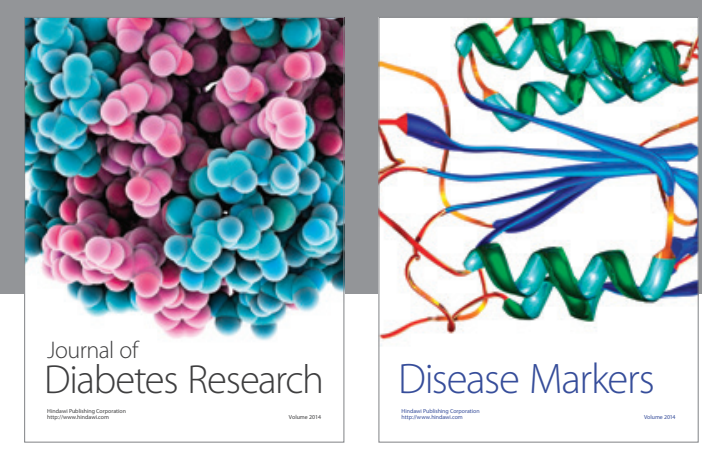

Disease Markers
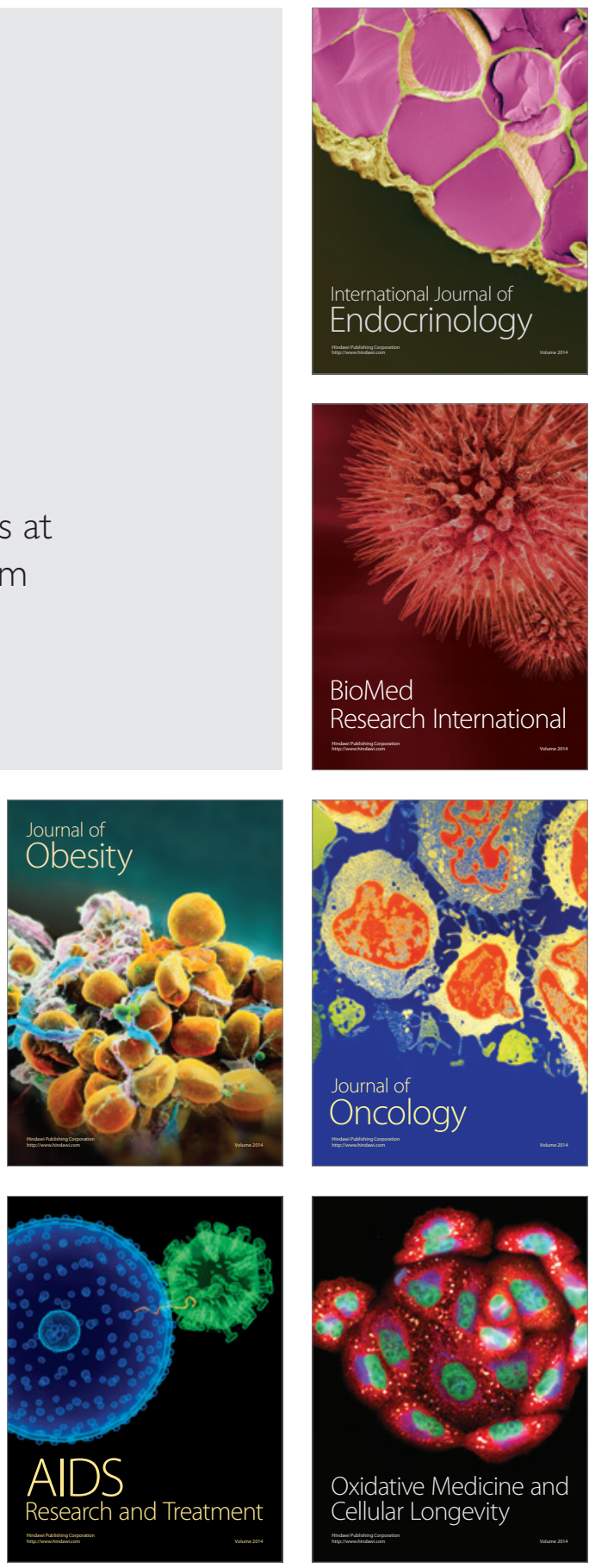